\title{
Initial growth of Schizolobium parahybae in Brazilian Cerrado soil under liming and mineral fertilization
}

\author{
Ademilson Coneglian ${ }^{1}$, Pedro H. P. Ribeiro², Bruno S. Melo ${ }^{1}$, Rennan F. Pereira ${ }^{3} \&$ Joáz Dorneles Junior ${ }^{4}$ \\ ${ }^{1}$ Universidade Estadual de Goiás. Ipemari, GO. E-mail: coneglian@ueg.br (Corresponding author); brunosilvagemeo@gmail.com \\ ${ }^{2}$ Universidade Federal de Uberlândia/Instituto Ciências Agrarias. Uberlândia, MG. E-mail: pedroirri@gmail.com \\ ${ }^{3}$ Universidade Federal da Paraíba/Centro de Ciências Agrárias. Areia, PB. E-mail: rennan.fp@gmail.com \\ ${ }^{4}$ Universidade Estadual Paulista “Julio de Mesquita Filho"/Faculdade de Ciências Agronômicas. Botucatu, SP. E-mail: joaz.dorneles@gmail.com
}

\section{Key words:}

Guapuruvu

native species

timber potential

\begin{abstract}
A B S T R A C T
High prices and the scarcity of hardwoods require the use of alternative wood sources, such as the Guapuruvu (Schizolobium parahybae), an arboreal species native to the Atlantic Forest, which has fast growth and high market potential. However, there is no information on its cultivation in the Brazilian Cerrado. Thus, this study aimed to analyze the contribution of mineral fertilization and liming in a Cerrado soil on the initial growth of Schizolobium parahybae. The experiment was set in a randomized block design, with 4 treatments (Cerrado soil; soil + liming; soil + fertilizer; and soil + fertilizer + liming) and 15 replicates. The following variables were analyzed: plant height, stem diameter, number of leaves, total, shoot, leaf, root and stem dry matter, and root/shoot ratio. The obtained data were subjected to the analysis of variance, Tukey test and regression analysis. During the initial growth, Schizolobium parahybae can be cultivated in a Brazilian Cerrado soil only under mineral fertilization, with no need for soil liming.
\end{abstract}

\section{Palavras-chave:}

Guapuruvu

espécie nativa

potencial madeireiro

\section{Crescimento inicial de Schizolobium parahybae em solo de cerrado brasileiro sobre calagem e adubação mineral}

\section{R E S U M O}

Os elevados preços e a escassez de madeiras nobres tornam necessário o uso de fontes alternativas de madeira, como guapuruvu (Schizolobium parahybae), espécie arbórea nativa da Mata Atlântica a qual apresenta rápido crescimento e alto potencial mercadológico; todavia, não há informações sobre seu cultivo no cerrado do Brasil; objetivou-se, neste sentido, analisar a contribuição da adubação mineral e da calagem no solo do cerrado sobre o crescimento inicial de Schizolobium parahybae. O delineamento foi em blocos casualizados, com 4 tratamentos (solo do cerrado; solo + calagem; solo + adubo; solo + adubo + calagem) e 15 repetições. As variáveis analisadas foram: altura de planta, diâmetro do caule, número de folhas, massas secas totais da parte aérea, das folhas, da raiz e do caule e relação raiz/ parte aérea. Os dados obtidos foram submetidos à análise de variância, ao teste de Tukey e à análise de regressão. Observou-se, durante o crescimento inicial, que o Schizolobium parahybae pode ser cultivado em solo do cerrado brasileiro apenas com adubação mineral sem a necessidade de calagem do solo. 


\section{INTRODUCTION}

Forest production in Brazil mainly refers to Pinus and Eucalyptus plantations, with the largest sustainable production in the Southeast region, followed by South, Northeast, Midwest and North (ABRAF, 2013). However, high prices and the scarcity of hardwoods make it necessary the use of alternative sources of wood, such as the Guapuruvu [Schizolobium parahybae (Vell.) S. F. Blake].

Schizolobium parahybae is an arboreal species, native to the Atlantic Forest, which occurs from the state of Bahia until Santa Catarina (Carvalho et al., 2008). It has great cultivation potential in the South and Southeast regions of Brazil, for its fast growth (Brienza Júnior et al., 1991), capacity to recover riparian forests, and many purposes in which its wood and bark can be used, besides being considered as a promising source of cellulose pulp (Ferreira et al., 2007).

There are few reports in the literature on the cultivation of Schizolobium parahybae subjected to soil fertilization and liming, which are essential practices to obtain better cultivation conditions (Chaves et al., 2011; Leal et al., 2013). Adami \& Hebling (2005) observed positive influence of phosphorus sources on the dry matter of parts of Schizolobium parahybae.

There is no information on the plantation of Schizolobium parahybae in the Brazilian Cerrado region. In order to use this native species in a commercial, rational way, it is necessary to develop cultivation techniques that make its production viable, especially in the beginning of the crop cycle.

Therefore, this study aimed to evaluate the initial growth of Guapuruvu (Schizolobium parahybae) in a Brazilian Cerrado soil under liming and NPK fertilization.

\section{Material AND Methods}

The study was carried out in a protected environment, from June to December 2014, at the State University of Goiás (UEG), located in the municipality of Ipameri, GO, Brazil (17043' 19" $\mathrm{S} ; 48^{\circ} 19^{\prime} 35^{\prime \prime} \mathrm{W} ; 773 \mathrm{~m}$ ), where the climate is tropical, with dry winter and humid summer (Aw), according to Köppen's classification.

The substrate was prepared using a dystrophic Red Latosol, collected in the layer of $0-20 \mathrm{~cm}$, in an area of the experimental farm of UEG, in Ipameri, GO. Soil chemical analysis was performed at the Solocria Agricultural Laboratory Ltda., with the following attributes: $\mathrm{pH}=5.2 ; \mathrm{P}=4.0 \mathrm{mg} \mathrm{dm}^{-3} ; \mathrm{K}=126.0$ $\mathrm{mg} \mathrm{dm}{ }^{-3} ; \mathrm{Ca}^{2+}=1.8 \mathrm{cmol} \mathrm{dm}^{-3} ; \mathrm{Mg}^{2+}=3.0 \mathrm{cmol}_{\mathrm{c}} \mathrm{dm}^{-3} ; \mathrm{Al}^{3+}=$ $0.0 \mathrm{cmol}_{\mathrm{c}} \mathrm{dm}^{-3} ; \mathrm{Zn}=2.9 \mathrm{mg} \mathrm{dm}^{-3} ; \mathrm{Fe}=61.1 \mathrm{mg} \mathrm{dm}^{-3} ; \mathrm{Mn}=$ $19.5 \mathrm{mg} \mathrm{dm}^{-3} ; \mathrm{Cu}=1.3 \mathrm{mg} \mathrm{dm}^{-3} ; \mathrm{B}=0.23 \mathrm{mg} \mathrm{dm}^{-3} ; \mathrm{H}+\mathrm{Al}=$ $2.2 \mathrm{cmol}_{\mathrm{c}} \mathrm{dm}^{-3}$; Sum of exchangeable bases $=3.12 \mathrm{cmol}_{\mathrm{c}} \mathrm{dm}^{-3}$; Effective cation exchange capacity $=3.12 \mathrm{cmol}_{\mathrm{c}} \mathrm{dm}^{-3}$; Cation exchange capacity at $\mathrm{pH} 7.0=5.32 \mathrm{cmol}_{\mathrm{c}} \mathrm{dm}^{-3}$; Base saturation index $=58.75 \%$; Aluminum saturation index $=0 \%$; Organic matter $=28 \mathrm{~g} \mathrm{dm}^{-3}$.

The studied treatments were: T1 - Cerrado soil (dystrophic Red Latosol); T2 - soil + liming; T3 - soil + fertilizer (1 $\mathrm{g} \mathrm{dm}^{-3}$ of soil of NPK formulation (5-30-15) + 0.2 of $\mathrm{Zn}+0.5$ of B); and T4 - soil + fertilizer $\left(1 \mathrm{~g} \mathrm{dm}^{-3}\right.$ of soil of NPK formulation $(5-30-15)+0.2$ of $\mathrm{Zn}+0.5$ of $\mathrm{B})+$ liming. The experiment was set in a randomized block design, with 15 replicates, totaling 60 experimental units.

The soil was sieved (4-mm mesh), and $5 \mathrm{dm}^{3}$ of this sieved material were placed in plastic bags, applying $1.25 \mathrm{~g}$ of dolomitic limestone $(\mathrm{RNV}=92 \%)$ per $\mathrm{dm}^{3}$ of soil (value based on the soil chemical analysis) in the 30 experimental units corresponding to the treatments 2 and 4 , which were incubated for the next 30 days. After this period, the plastic bags were opened and remained at rest for 2 days in order to evaporate the exceeding volume of water, maintaining the gravimetric water content close to field capacity.

In the treatments 3 and 4 , soil chemical analysis data were used to determine the application of the NPK formulation (5-30-15), which corresponded to $1 \mathrm{~g} \mathrm{dm}^{-3}$ for a soil volume of $5 \mathrm{dm}^{3}$.

Then, the soil materials corresponding to each plot were transferred to black plastic pots with capacity for $5 \mathrm{dm}^{3}$, perforated at the bottom perimeter and placed in a greenhouse.

The seedlings of Schizolobium parahybae used in the experiment were prepared with seeds obtained in the city of Pederneiras, São Paulo State, Brazil, from matrices homologated and registered by the Coordination of Integral Technical Assistance (CATI, SP).

Initially, seeds of Schizolobium parahybae underwent a process of dormancy break through immersion in boiling water at $95{ }^{\circ} \mathrm{C}$ for $10 \mathrm{~min}$ and, immediately after, they remained immersed in water at room temperature for $48 \mathrm{~h}$, as recommended by Bianchetti \& Ramos (1981).

Then, seeding was performed in sand seedbed, which was daily watered thenceforth. At 15 days after seeding (DAS), when plants showed mean height of $9 \mathrm{~cm}$, the seedlings were transplanted to plastic pots containing soil prepared according to the established treatments.

After transplanting the seedlings of Schizolobium parahybae, daily waterings were performed using a 1-L beaker, as suggested by Costa et al. (2006) for the control of soil moisture.

The following variables were biweekly measured from 15 to 60 days after transplantation (DAT): plant height, in $\mathrm{cm}$, from the base to the apex of the plants, using a ruler; stem diameter, in $\mathrm{mm}$, using a digital caliper; and number of leaves.

At 60 DAT (or 90 DAS), all the plants were separated into leaves, stems and roots, washed and dried in a forced-air oven at $65^{\circ} \mathrm{C}$ for $72 \mathrm{~h}$ until constant weight, in order to determine the following variables: total dry matter (TDM), in g; shoot dry matter (ShDM), in g; leaf dry matter (LDM), in g; root dry matter (RDM), in g; stem dry matter (StDM), in g; and the ratio between root and shoot matters $(\mathrm{R} / \mathrm{S})$.

The obtained results were subjected to the analysis of variance by $F$ test $(\mathrm{p}<0.01$ and 0.05$)$, and treatment means were compared by Tukey test $(\mathrm{p}<0.05)$. In addition, regression analysis was performed for plant height and stem diameter as a function of the days after transplantation. Statistical analyses were performed using the program Assistat, Silva \& Azevedo (2009).

\section{Results AND Discussion}

Table 1 shows the summary of the analysis of variance for plant height, stem diameter and number of leaves of 
Table 1. Summary of analysis of variance for plant height, stem diameter and number of leaves of Guapuruvu (Schizolobium parahybae) subjected to treatments of soil nutritional correction, at 15, 30, 45 and 60 days after transplanting (DAT)

\begin{tabular}{|c|c|c|c|c|c|}
\hline \multirow{2}{*}{$\begin{array}{c}\text { Source } \\
\text { of variation }\end{array}$} & \multirow{2}{*}{ DF } & \multicolumn{4}{|c|}{ Mean square (plant height) - DAT ${ }^{1}$} \\
\hline & & 15 & 30 & 45 & 60 \\
\hline Treatment & 3 & $624.93^{* *}$ & $689.97^{* *}$ & $634.91^{\star *}$ & $617.98^{* *}$ \\
\hline Replicate & 14 & 20.7 & 21.14 & 19.72 & 19.73 \\
\hline Residue & 42 & 17.55 & 19.73 & 17.09 & 16.83 \\
\hline CV (\%) & & 14.74 & 15.13 & 13.08 & 12.34 \\
\hline Treatment & 3 & $11.1^{\star \star}$ & $11.12^{\star \star}$ & $18.12^{\star \star}$ & $20.38^{* \star}$ \\
\hline Replicate & 14 & 2.22 & 2.39 & 1.84 & 4.38 \\
\hline Residue & 42 & 1.83 & 1.99 & 2.3 & 3.85 \\
\hline CV (\%) & & 13.65 & 13.37 & 13.22 & 16.15 \\
\hline Treatment & 3 & $0.99^{\text {ns }}$ & $0.11^{\mathrm{ns}}$ & $0.46^{\mathrm{ns}}$ & $0.028^{\text {ns }}$ \\
\hline Block & 14 & 0.38 & 0.03 & 0.40 & 0.04 \\
\hline Residue & 42 & 0.47 & 0.05 & 0.23 & 0.048 \\
\hline CV (\%) & & 19.99 & 19.09 & 16.23 & 17.54 \\
\hline
\end{tabular}

DF - Degrees of freedom; ${ }^{1}$ Data transformed to the square root of $X ;{ }^{* *}$ Significant at $p<0.01$

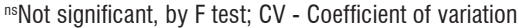

Guapuruvu (Schizolobium parahybae), measured at 15, 30, 45 and 60 DAT. Plant height and stem diameter were significantly affected by the studied treatments in the analyzed periods ( $\mathrm{p}$ $<0.01$ ), according to the F test.

The parameter number of leaves was not significantly influenced by the studied treatments in any of the analyzed periods (Table 1). The mean value for this variable, between 15 and 60 DAT, was 1.3 leaves per plant. Likewise, Adami \& Hebling (2005), studying P sources on the initial growth of Schizolobium parahybae, did not observe significant effects of the treatments on number of leaves.

The highest values of plant height were observed in Schizolobium parahybae plants subjected to the treatment with soil and mineral fertilization (T3), regardless of the analyzed period, which were $19.86,21.99,14.42$ and $14.15 \%$ higher compared with plants in the treatment T4 (soil + fertilizer + liming), at 15, 30, 45 and 60 DAT, respectively (Figure 1A). In addition, plants subjected to T1 (only Cerrado soil) and T2 (soil + liming), in all evaluation periods, showed the lowest values of plant height and did not differ significantly by Tukey test $(\mathrm{p}<0.05)$ (Figure 1A).

Stem diameter, among others, can be considered one of the most important variables in the study of wood-producing species. There were no significant differences for the means of stem diameter between plants subjected to the treatments $\mathrm{T} 3$ (soil + fertilizer) and T4 (soil + fertilizer + liming) at 15, 30, 45 and 60 DAT (Figure 1B), indicating that fertilization alone can be sufficient to meet the nutritional requirements of Schizolobium parahybae during its initial growth.

As observed for plant height (Figure 1A), the lowest values of stem diameter (Figure 1B) were obtained in plants under the treatments T1 (Cerrado soil) and T2 (soil + liming), which suggests that the highest values of plant height and stem diameter occurred in the treatments T3 (soil + fertilizer) and T4 (soil + fertilizer + liming) were caused by the NPK fertilization, with no effect of soil liming on these variables.

According to Foloni et al. (2008), liming with the adequate dose of limestone neutralizes active soil acidity. However, in the present study, although the limestone dose was determined
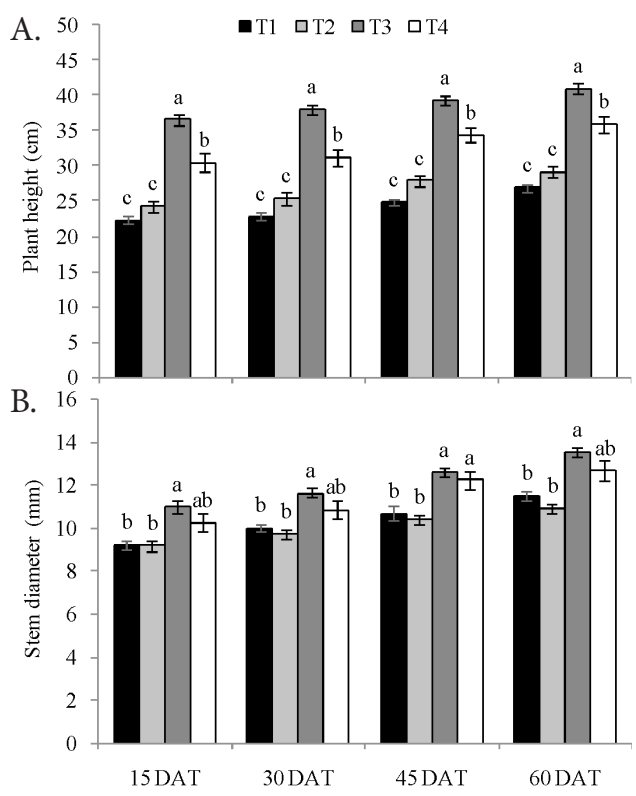

T1 - Cerrado soil; T2 - soil + liming; T3 - soil + fertilizer; T4 - soil + fertilizer + liming. Means with the same letter for given period do not differ significantly

Figure 1. Plant height (A) and stem diameter (B) of Guapuruvu (Schizolobium parahybae) subjected to soil nutritional correction, at 15, 30, 45 and 60 days after transplantation (DAT)

based on the results of the soil chemical analysis, the values of plant height and stem diameter of plants under soil liming (T2 - soil + liming) did not differ from control plants (T1 only Cerrado soil).

These results show that Guapuruvu has certain tolerance to slightly acid soils, since the $\mathrm{pH}$ of the soil used in this study, before liming and NPK application, was equal to 5.2. This $\mathrm{pH}$ may have provided fertility values sufficient for the initial growth of the crop, as shown by Vale et al. (1996).

All data referring to plant height (Figure 2A) and stem diameter (Figure 2B) of Schizolobium parahybae, regardless of the treatment of soil nutritional correction, fitted to linear models and increased along the days after transplantation. However, the highest values of plant height and stem diameter were observed in plants subjected to the treatments 3 and 4 (Figures $1 \mathrm{~A}, 1 \mathrm{~B}, 2 \mathrm{~A}$ and $2 \mathrm{~B}$ ), possibly due to the NPK fertilization.

It is of great importance the knowledge on treatments that increase the growth speed of wood-producing plants, aiming to increment production in a shorter time, in order to fit and compete in the market, because the wood sector in Brazil is mainly composed of fast-growing forest plantations (Vidal et al., 2015).

The treatments of soil nutritional correction significantly affected total dry matter $(\mathrm{p}<0.01)$, shoot dry matter $(\mathrm{p}<$ $0.01)$, leaf dry matter $(\mathrm{p}<0.01)$, root dry matter $(\mathrm{p}<0.05)$ and stem dry matter $(\mathrm{p}<0.01)$ of Schizolobium parahybae, but no effect was observed on the root/shoot ratio (Table 2 ). The mean value of root/shoot ratio was 0.7 , i.e., the mass of roots of Schizolobium parahybae, at 60 DAT (90 DAS), was equivalent to $70 \%$ of the mass of shoots.

Total dry matter (Figure 3A) and shoot dry matter (Figure 3B) of Schizolobium parahybae were positively influenced by the treatments T2 (soil + liming), T3 (soil + fertilizer) and 


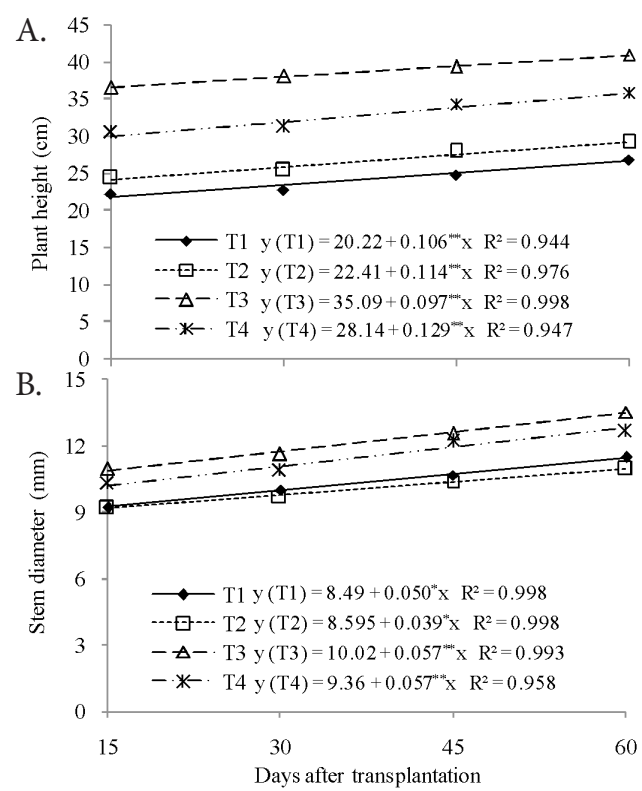

Figure 2. Plant height (A) and stem diameter (B) of Guapuruvu (Schizolobium parahybae) as a function of days after transplantation

T4 (soil + fertilizer + liming), which did not differ by Tukey test, while leaf dry matter (Figure $3 \mathrm{C}$ ) increased under the treatments T2 (soil + liming) and T4 (soil + fertilizer + liming), possibly because of the benefits of soil liming, such as the improvement in $\mathrm{P}$ mineralization, increase in mineralization, $\mathrm{N}$ nitrification (Chatzistathis et al., 2015).

The values of root dry matter (Figure 3D) of Schizolobium parahybae cultivated in soils corrected with limestone (T2 and T4) were higher, probably due to a possible increase in $\mathrm{pH}, \mathrm{Ca}, \mathrm{Mg}$ and base saturation, as well as a reduction in $\mathrm{H}+$ $\mathrm{Al}$, exchangeable $\mathrm{Al}$ and $\mathrm{Al}$ saturation, as observed by Auler et al. (2011).

Nevertheless, with respect to root dry matter (Figure 3D), plants under the treatment with soil + fertilizer (T3) did not differ statistically from plants under liming treatments (T2 and T4), an additional evidence that NPK fertilization, in the absence of limestone, promoted favorable conditions for the initial growth of Schizolobium parahybae.

Stem dry matter - an important variable, since it refers to the part of Schizolobium parahybae of greatest commercial importance - was higher in plants under the treatment T3 (soil + fertilizer), followed by T4 (soil + fertilizer + liming), as shown in Figure 3E. This indicates that this species can be cultivated under the studied conditions, with no need for soil liming, in order to reduce production costs.
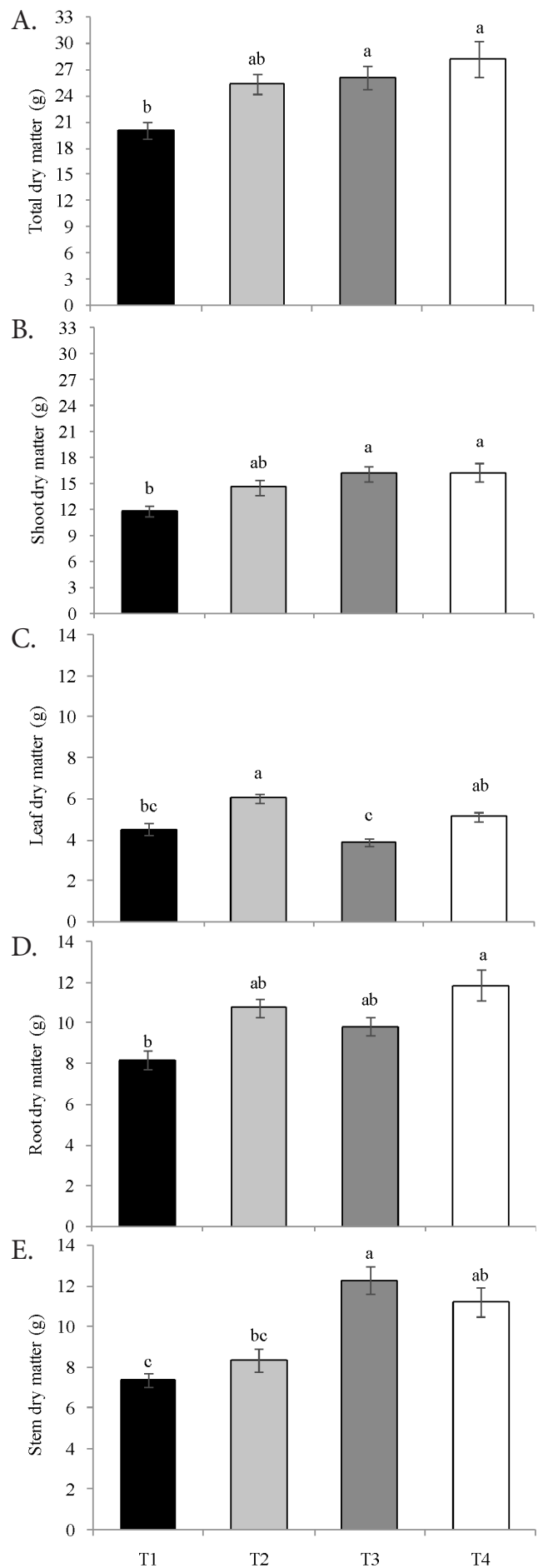

T1 - Cerrado soil; T2 - soil + liming; T3 - soil + fertilizer; T4 - soil + fertilizer + liming Means with the same letter do not differ significantly

Figure 3. Total dry matter (A), shoot dry matter (B), leaf dry matter $(\mathrm{C})$, root dry matter (D) and stem dry matter of Guapuruvu (Schizolobium parahybae) subjected to treatments of soil nutritional correction

Table 2. Summary of analysis of variance for total dry matter (TDM), shoot dry matter (ShDM), leaf dry matter (LDM), root dry matter (RDM), stem dry matter (StDM) and root/shoot ratio (R/S) of Guapuruvu (Schizolobium parahybae) subjected to treatments of soil nutritional correction

\begin{tabular}{cccccccc}
\hline \multirow{2}{*}{ Source of variation } & \multirow{2}{*}{ DF } & \multicolumn{9}{c}{ Mean square } \\
\cline { 3 - 8 } & & TDM & ShDM & LDM & RDM & StDM & R/S \\
Treatment & 3 & $179.30^{* \star}$ & $64.37^{* *}$ & $12.42^{* \star}$ & $36.39^{\star}$ & $78.19^{* *}$ & $0.05^{\text {ns }}$ \\
Block & 14 & 18.01 & 10.34 & 0.95 & 4.62 & 7.60 & 0.03 \\
Residual & 42 & 34.20 & 12.28 & 1.35 & 9.29 & 7.85 & 0.03 \\
CV (\%) & & 23.51 & 23.79 & 12.14 & 15.00 & 14.43 & 25.88 \\
\hline
\end{tabular}

DF - Degrees of freedom; ${ }^{\text {ns }}{ }^{* *}$ and ${ }^{*}$ Not significant and significant at $p<0.01$ and $p<0.05$, respectively; by F test; CV - Coefficient of variation 


\section{Conclusion}

During the initial growth, until 60 days after seeding, the Guapuruvu (Schizolobium parahybae) can be grown in soil from the Brazilian Cerrado with $\mathrm{pH}$ of 5.2, under only mineral fertilization, with no need for soil liming.

\section{Literature Cited}

ABRAF - Associação Brasileira de Produtores de Florestas Plantadas. Anuário estatístico da ABRAF, 2013. <http://www.abraflor.org. br>. 1 Abr. 2014.

Adami, C.; Hebling, S. Efeitos de diferentes fontes de fósforo no crescimento inicial de Schizolobium parahyba (Vell.) S. F. Blake. Natureza on line, v.3, p.13-18, 2005.

Auler, P. A.; Neves, C. S. V. J.; Fidalski, J.; Pavan, M. A. Calagem e desenvolvimento radicular, nutrição e produção de laranja 'Valência' sobre porta-enxertos e sistemas de preparo do solo. Pesquisa Agropecuária Brasileira, v.46, p.254-261, 2011. http:// dx.doi.org/10.1590/S0100-204X2011000300005

Bianchetti, A.; Ramos, A. Quebra de dormência de guapuruvu (Schizolobium parahyba (Vellozo) Blake). Boletim de Pesquisa Florestal, n.3, p.69-76, 1981.

Brienza Júnior, S.; Yared, J. A. G.; Jarvis, P. G. Agroforestry systems as an ecological approach in the Brazilian Amazon development. Agroforestry Systems, v.45, p.319-323, 1991. http://dx.doi. org/10.1016/0378-1127(91)90226-1

Carvalho, M. G.; Nascimento, I. A; Carvalho, A. G. 5-desoxiflavonóides e lignana isolados da madeira de Schizolobium parahyba (Vell.) S. F. Blake (guapuruvu). Química Nova, v.31, p.1349-1352, 2008. http://dx.doi.org/10.1590/S0100-40422008000600014

Chatzistathis, T.; Alifragis, D.; Papaioannou, A. The influence of liming on soil chemical properties and on the alleviation of manganese and copper toxicity in Juglans regia, Robinia pseudoacacia, Eucalyptus sp. and Populus sp. plantations. Journal of Environmental Management, v.150, p.149-156, 2015. http:// dx.doi.org/10.1016/j.jenvman.2014.11.020
Chaves, L. H. G.; Gheyi, H. R.; Ribeiro, S. Consumo de água e eficiência do uso para cultivar de mamona paraguaçu submetida à fertilização nitrogenada. Engenharia Ambiental, v.8, p.126-133, 2011.

Costa, A. M.; Gobbi, E. L.; Demuner, V. G.; Hebling, S. A. O efeito da inundação do solo sobre o crescimento inicial de Schizolobium parahyba (Vell.) S. F. Blake, guapuruvu. Natureza on line, v.4, p.7-13, 2006.

Ferreira, R. A.; Oliveira, L. M.; Tonetti, O. A. O.; Davide, A. C. Comparação da viabilidade de sementes de Schizolobium parahyba (Vell.) Blake - leguminosae caesalpinioideae, pelos testes de germinação e tetrazólio. Revista Brasileira de Sementes, v.29, p.83-89, 2007. http://dx.doi.org/10.1590/S010131222007000300011

Foloni, J. S. S.; Santos, D. H.; Creste, J. E.; Salvador, J. P. Resposta do feijoeiro e fertilidade do solo em função de altas doses de calcário em interação com a gessagem. Colloquium Agrariae, v.4, p.27-35, 2008. http://dx.doi.org/10.5747/ca.2008.v04. n2.a 037

Leal, A. J. F.; Lazarini, E.; Rodrigues, L. R.; Marcandalli, L. H. Plantas de cobertura e modos de aplicação de calcário. Revista Brasileira de Ciência do Solo, v.37, p.491-501, 2013. http://dx.doi. org/10.1590/S0100-06832013000200020

Silva, F. de A. S. e; Azevedo, C. A. V. de. Principal components analysis in the software Assistat-Statistical attendance. In: World Congress on Computers in Agriculture, 7, 2009, Reno. Proceedings... Reno: American Society of Agricultural and Biological Engineers, 2009. CD Rom

Vale, F. R.; Furtini Neto, A. E.; Renó, N. B.; Fernandes, L. A.; Resende, A. V. Crescimento radicular de espécies florestais em solo ácido. Pesquisa Agropecuária Brasileira, v.31, p.609-616, 1996.

Vidal, J. M.; Evangelista, W. V.; Silva, J. C.; Jankowsky, I. P. Preservação de madeiras no Brasil: Histórico, cenário atual e tendências. Ciência Florestal, v.25, p.257-271, 2015. http://dx.doi. org/10.5902/1980509817484 